\title{
Effect of feeding history on milk production and plasma IGF-1 level in indigenous Ethiopian and crossbred cows*
}

\author{
A. Jenet ${ }^{1,2}$, S. Fernandez-Rivera ${ }^{1}$, H.R. Wettstein ${ }^{2}$, M. Kreuzer ${ }^{2,4}$, \\ W. Langhans ${ }^{3}$, D. Werling ${ }^{3}$ and M. Senn ${ }^{3}$ \\ ${ }^{1}$ International Livestock Research Institute (ILRI) \\ P.O. Box 5689, Addis Ababa, Ethiopia \\ Institute of Animal Science, Federal Institute of Technology (ETH) ETH-Centre/LFW \\ ${ }^{2}$ Animal Nutrition, \\ ${ }^{3}$ Physiology and Animal Husbandry \\ $\mathrm{CH}-8092$ Zurich, Switzerland
}

\begin{abstract}
Seasonal fluctuations in feed supply often result in serious under-nutrition of dairy cattle. We investigated the effects of impairments and improvements of feeding levels on milk production, weight changes, and the plasma level of IGF-1 in the third lactation of 27 Boran (Bos indicus) and Holstein-Boran crossbred cows. Results showed that Boran cows responded to changes in feed supply with weight changes and crossbreds predominantly with changes in milk yield. Milk yield was generally higher in crossbred cows; however, cows previously well fed showed higher milk production levels. IGF-1 was highest in Boran cows. Also crossbreds, well fed after previous undernutrition, showed high plasma levels of IGF-1, suggesting that these cows replenish first their body reserves at the expenses of milk production.
\end{abstract}

KEY WORDS: Bos indicus, dairy, IGF-1, body weight changes, under-nutrition, re-feeding

\section{INTRODUCTION}

Dairy farming in tropical countries is often challenged by drastic seasonal fluctuations in feed supply. Responding to the growing demand in dairy products in developing countries, farmers increasingly use crossbred genotypes; however, this is not always followed by improvements. Unbalanced nutrients or low quality of feeds, but also high disease pressure, reduce the advantages of the upgraded

\footnotetext{
* Supported by the Swiss Centre for International Agriculture (ZIL/SDC)

${ }^{4}$ Corresponding author: e-mail: michael.kreuzer@inw.agrl.ethz.ch
} 
breeds. To develop feeding strategies for either rural or urban areas in tropical regions, relevant for both domestic and crossbred dairy genotypes, the effects of feed improvements or impairments should be taken into consideration.

In the present study, the effects of an improved and an impaired feed supply on body weight changes, milk yield and the plasma level of the insulin-like growth factor-1 (IGF-1) as an indicator of the somatotropin axis were investigated.

\section{MATERIAL AND METHODS}

Sixteen heifers of Zebu origin (Boran) and 16 crossbreds (Holstein $\times$ Boran, $\mathrm{B} \times \mathrm{H}$; F1 and B1) were fed on a high or a low feeding level $\left(\mathrm{H}_{\mathrm{H}}\right.$ or $\mathrm{H}_{\mathrm{L}}$, where $\mathrm{H}$ stands for the feeding history) from a body weight (BW) of $300 \mathrm{~kg}$ until the end of lactation 2 (cf. Jenet et al., 2004). Feeding levels were calculated to cover either 1.0 or $1.4 \times$ maintenance energy requirements (AFRC, 1993). In lactation 3, half of the $\mathrm{H}_{\mathrm{H}}$ cows were reallocated to the low feeding level $\left(\mathrm{F}_{\mathrm{L}}\right.$, where $\mathrm{F}$ is the actual feeding level), and half of the $\mathrm{H}_{\mathrm{L}}$ cows were switched to the high feeding level $\left(\mathrm{F}_{\mathrm{H}}\right)$. The remaining $\mathrm{H}_{\mathrm{H}}$ and $\mathrm{H}_{\mathrm{L}}$ cows continued on their original feeding level. This generated the following four groups for each genotype: $\mathrm{H}_{\mathrm{L}} \mathrm{F}_{\mathrm{L}}, \mathrm{H}_{\mathrm{L}} \mathrm{F}_{\mathrm{H}}, \mathrm{H}_{\mathrm{H}} \mathrm{F}_{\mathrm{L}}$ and $\mathrm{H}_{\mathrm{H}} \mathrm{F}_{\mathrm{H}}$. Overall, this resulted in a $2 \times 2 \times 2$-factorial arrangement with eight treatment groups and genotype, feeding history and actual feeding level as factors in lactation 3. Only 27 cows entered lactation 3, mostly due to (nutritionally caused) infertility. Diets always consisted of proportionately $65 \%$ grass hay (mainly Cynodon dactylon) and 35\% wheat bran of total dietary dry matter (DM), and feed was provided once daily after morning milking. Feed offered and refused was recorded daily throughout lactation 3. Every second week BW and body condition scores (BCS; applying a scale from meagre $=1$ to obese $=9$; Nicholson and Butterworth, 1986) were recorded. Calves were weaned not before day 60 of lactation. This practice was implemented because Boran cows required the stimulus for milk release. Milk yield was calculated as the sum of twice daily milked harvest and the milk suckled by the calf. Blood samples were collected 78 days after calving from the jugular vein $5 \mathrm{~h}$ after the last allocation of feed. The heparinized samples were immediately centrifuged and plasma was stored. Plasma levels of IGF-1 were determined by an immuno-enzymometric assay (Octeia, IDS, Boldon, UK). For analysis of variance, the general linear model (GLM) of SAS (version 8.12, SAS institute Inc.) was employed to account for unbalanced treatments based on the following model:

$$
Y_{i j k}=\mu+\alpha_{i}+\beta_{j}+\gamma_{k}+\alpha \beta_{i j}+\beta \gamma_{j k}+\alpha \gamma_{i k}+\alpha \beta \gamma_{i j k}+e_{i j k l}
$$

where $\mathrm{Y}_{\mathrm{ijk}}=$ individual observation, $\mu=$ overall mean, $\alpha_{\mathrm{i}}=$ effect of genotype $(\mathrm{G})$, $\beta_{\mathrm{j}}=$ effect of actual feeding level $(\mathrm{F}), \gamma_{\mathrm{k}}=$ effect of previous feeding level $(\mathrm{H})$, and $\mathrm{e}_{\mathrm{ijkl}}=$ residual error. 


\section{RESULTS}

Body weight changes differed between feeding levels $(\mathrm{P}<0.1)$. Cows with $\mathrm{F}_{\mathrm{L}}$ treatments had higher weight losses (Figure 1). Milk production differed between genotypes $(\mathrm{P}<0.001)$, with higher yields for crossbred cows. Feeding history had an effect $(\mathrm{P}<0.1)$ on the milk yield of cows, resulting in a lower yield of previously underfed $\left(\mathrm{H}_{\mathrm{L}}\right)$ crossbred cows. IGF-1 plasma levels generally were higher $(\mathrm{P}<0.05)$ in Boran cows than in the crossbreds.
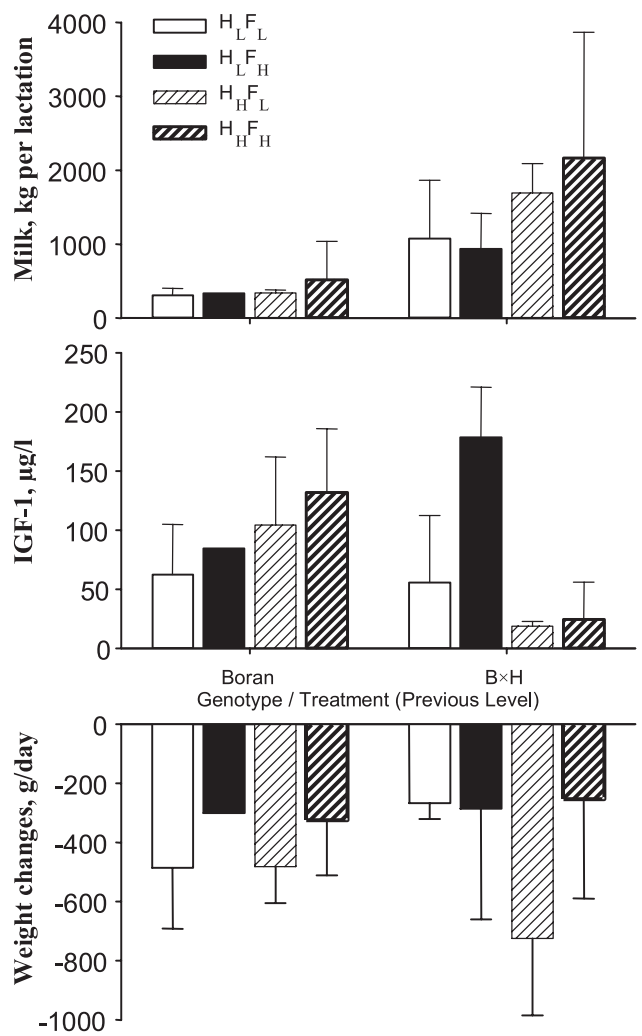

Figure 1. Relationships of genotype, previous and actual feeding level on milk yield, plasma IGF-1 and BW changes. The horizontal bars represent the standard errors

\section{DISCUSSION}

Results revealed clearly different patterns of response between genotypes in milk production and large effects of the feeding history in crossbred cows. Boran cows did not react to changes in feed supply by increasing milk production, but the improved feed supply reduced the weight loss in mid lactation. Milk production in crossbred cows was affected by the feeding history. Low previous feed supply $\left(\mathrm{H}_{\mathrm{L}}\right)$ reduced actual milk production in crossbred cows. Instead of producing more 
milk, $\mathrm{H}_{\mathrm{L}} \mathrm{F}_{\mathrm{H}}$ crossbred cows showed lower weight losses and increased IGF-1 plasma levels, indicative for replenishing body reserves at the expense of milk production.

In contrast, $\mathrm{H}_{\mathrm{H}} \mathrm{F}_{\mathrm{L}}$ crossbred cows, adapted to a high level of milk production, tried to maintain their level of milk production, when exposed to under-nutrition, by increasing body mobilization. Elevated plasma IGF-1 concentrations, as seen in $\mathrm{F}_{\mathrm{H}}$ Boran cows, are indicative for up-regulated oxidative metabolism, cell growth and heat production. The high BCS and BW, as well as an estimation of maintenance energy requirements (data not shown) support the assumption that $\mathrm{H}_{\mathrm{H}}$ Boran cows had an elevated heat production. In contrast the low IGF-1 in cows with high milk production resulted probably in decreased adipose conversion of pre-adipose cell lines, which is regulated by IGF-1 and growth hormone (Boone et al., 2000). Consequently, plasma concentrations of IGF-1 are typically reduced in starvation (McGuire et al., 1998). Consistent with the low plasma IGF-1 in starvation, the re-alimented, i.e. $\mathrm{H}_{\mathrm{L}} \mathrm{F}_{\mathrm{H}}$ crossbred cows of our study, had high plasma levels of IGF-1 and partitioned less energy into milk in contrast to other crossbred groups.

\section{CONCLUSIONS}

Carry-over effects resulting from previous planes of nutrition can affect cows. Both, a restriction and an improvement had an effect on milk secretion and BW changes in crossbred cows in mid lactation. Milk secretion of Bos indicus (here: Boran) cows seemed not to be influenced by any feeding changes, maybe because of their comparable low metabolic rate. Borans responded to increases in feed supply with generally high plasma IGF-1 concentrations accompanied with BW changes. With their constantly low secretion of milk, Boran cows are saving energy for feed scarcity associated with seasonal droughts. Feed fluctuation has more detrimental effects on crossbred cows, which in turn have advantages in terms of milk productivity and therefore in peri-urban areas.

\section{REFERENCES}

AFRC (Agricultural and Food Research Council), 1993. Energy and Protein Requirements of Ruminants. CAB International, Wallingford (UK)

Boone C., Mourot J., Gregoire F., Remacle C., 2000. The adipose conversion process: Regulation by extracellular and intracellular factors. Reprod. Nutr. Develop. 40, 325-358

Jenet A., Yimegnuhal A., Fernandez-Rivera S., Tegegne A., Osuji P.O., McCrabb G.J., Kreuzer M., 2004. Long-term response to feeding level in lactational performance of Boran (Bos indicus) and Boran $\times$ Holstein cows. Anim. Sci. 78, 331-343

McGuire M.A., Dwyer D.A., Bauman D.E., Smith D.F., 1998. Insulin-like growth factors in plasma and afferent mammary lymph of lactating cows deprived of feed or treated with bovine somatotropin. J. Dairy Sci. 81, 950-957

Nicholson M.J., Butterworth M.H., 1986. A Guide to Condition Scoring of Zebu Cattle. International Livestock Centre for Africa, Addis Ababa (Ethiopia) 